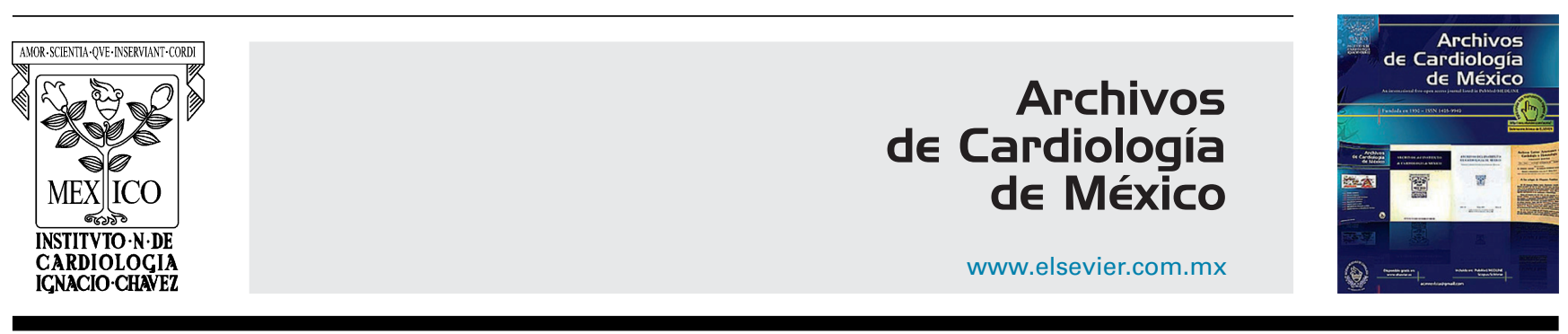

OPINION ARTICLE

\title{
Inferior vena cava filters in pulmonary embolism: A historic controversy
}

\section{Carlos Jerjes-Sanchez ${ }^{\mathrm{a}, \mathrm{b}, *}$, David Rodriguez ${ }^{\mathrm{b}}$, Aline Navarrete ${ }^{\mathrm{c}}$, Carolina Parra-Cantu ${ }^{c}$, Jorge Joya-Harrison ${ }^{c}$, Eduardo Vazquez ${ }^{b}$, Alicia Ramirez-Rivera ${ }^{d}$}

\author{
a Instituto de Cardiología y Medicina Vascular, TEC Salud and Centro de Investigacion Biomedica del Hospital Zambrano Hellion, \\ Escuela de Medicina, Tecnologico de Monterrey, Mexico \\ ${ }^{\mathrm{b}}$ Centro de Investigacion Biomedica del Hospital Zambrano Hellion, TEC Salud, Escuela de Medicina, Tecnologico de Monterrey, \\ Mexico \\ ' Escuela de Medicina, Tecnologico de Monterrey, Mexico \\ d Departamento de Fisiología Pulmonar, Laboratorio del Sueño y Clinica de Hipertension Pulmonar, UMAE 34 Hospital de \\ Cardiologia, IMSS, Monterrey, Mexico
}

Received 2 November 2016; accepted 20 January 2017

\author{
KEYWORDS \\ Pulmonary embolism; \\ Deep venous \\ thrombosis; \\ Venous \\ thromboembolism; \\ Inferior vena cava \\ filters; \\ Mexico
}

\begin{abstract}
Objective: Rationale for non-routine use of inferior venous cava filters (IVCF) in pulmonary embolism (PE) patients.

Methods: Thrombosis mechanisms involved with IVCF placement and removal, the bloodcontacting medical device inducing clotting, and the inorganic polyphosphate in the contact activation pathway were analyzed. In addition, we analyzed clinical evidence from randomized trials, including patients with and without cancer. Furthermore, we estimated the absolute risk reduction (ARR), the relative risk reduction (RRR), and the number needed to treat (NNT) based on the results of each study using a frequency table. Finally, we analyzed the outcome of our PE patients that were submitted to thrombolysis with short and long term follow-up.

Results: IVCF induces thrombosis by several mechanisms including placement and removal, rapid protein adsorption, and simultaneous surface-induced activation via the contact activation pathway. Also, inorganic polyphosphate has an important role as a procoagulant, reversing the effect of anticoagulants. Randomized control trials included 904 cancer and non-cancer PE patients. In terms of ARR, RRR, and NNT, there is no evidence for routine use of IVCF. In 290 patients with proved $\mathrm{PE}$, extensive thrombotic burden and right ventricular dysfunction under thrombolysis and oral anticoagulation, we observed a favorable outcome in a short- and long-term follow-up; additionally, IVCF was only used in 5\% of these patients.
\end{abstract}

\footnotetext{
* Corresponding author at: Batallón de San Patricio 112, Real San Agustin, CP 66278, San Pedro Garza Garcia, Nuevo Leon, Mexico. Tel.: +5288880000 .

E-mail addresses: jerjes@prodigy.net.mx, carlos.jerjes@udicem.org.mx (C. Jerjes-Sanchez).
} 
Conclusion: Considering the complex mechanisms of thrombosis related with IVCF, the evidence from randomized control trials and ARR, RRR, and NNT obtained from venous thromboembolism patients with and without cancer, non-routine use of IVCF is recommended.

(C) 2017 Instituto Nacional de Cardiología Ignacio Chávez. Published by Masson Doyma México S.A. This is an open access article under the CC BY-NC-ND license (http://creativecommons. org/licenses/by-nc-nd/4.0/).

\section{PALABRAS CLAVE}

Tromboembolia pulmonar; Trombosis venosa profunda; Tromboembolismo venoso; Filtros de vena cava inferior; México
Filtros de vena cava inferior en tromboembolia pulmonar: Una controversia histórica

\section{Resumen}

Objetivo: Racionalidad para no utilizar en forma rutinaria filtros de vena cava inferior (FVCl) en pacientes con tromboembolia pulmonar (TEP).

Métodos: Analizamos mecanismos de trombosis relacionados con la colocación o retiro de estos dispositivos médicos, incluyendo la importancia del polifosfato inorgánico en la vía de activación de contacto. Analizamos evidencia clínica de estudios aleatorizados controlados en pacientes con y sin cáncer. Mediante tablas de frecuencia estimamos de cada estudio reducción del riesgo absoluto (RRA) y relativo (RRR) y el número necesario a tratar (NNT). Finalmente, examinamos la evolución de nuestros pacientes con TEP llevados a trombolisis con seguimientos a corto y largo plazo.

Resultados: $\mathrm{FVCI}$ inducen trombosis por diferentes mecanismos: colocación y retiro, adsorción rápida de proteínas y activación de superficie inducida en la vía de activación de contacto. El polifosfato inorgánico es un procoagulante importante para la anticoagulación. Estudios aleatorizados controlados incluyeron 904 pacientes con TEP con y sin cáncer. En términos de RRA, RRR y NNT no existe evidencia para el uso rutinario. En 290 pacientes con TEP probada, importante carga de trombo y disfunción del ventrículo derecho llevados a trombolisis y anticoagulación observamos una evolución favorable en seguimientos a corto y largo plazo. En estos pacientes los $\mathrm{FVCl}$ se utilizaron solo en el $5 \%$.

Conclusión: Considerando los mecanismos complejos de trombosis relacionados con los $\mathrm{FVCl}$, la evidencia obtenida de los estudios aleatorizados y controlados, así como la RRA, RRR y NNT en pacientes con tromboembolismo venoso con y sin cáncer, no recomendamos el uso rutinario de $\mathrm{FVCl}$.

(C) 2017 Instituto Nacional de Cardiología Ignacio Chávez. Publicado por Masson Doyma México S.A. Este es un artículo Open Access bajo la licencia CC BY-NC-ND (http://creativecommons. org/licenses/by-nc-nd/4.0/).

\section{Introduction}

Pulmonary embolism (PE) is the third cause of cardiovascular mortality $(100,000$ deaths per year) after myocardial infarction and stroke. In addition, it is the leading preventable cause of death in-hospital patients, the main cause of pregnancy-related maternal death in developed countries, and the second cause of death in patients with cancer. ${ }^{1-3}$ Also, PE and deep venous thrombosis (DVT), often referred to as venous thromboembolism (VTE), are the third cause of cardiovascular disability, impair quality of life, and cause major long-term complications related with recurrence, chronic thromboembolic pulmonary hypertension, and postthrombotic syndrome. ${ }^{1}$ Guidelines from European Society of Cardiology recommend the use of inferior vena cava filters (IVCF) in patients with acute PE, who have absolute contraindications to use of anticoagulant drugs and with objectively confirmed recurrent $\mathrm{PE}$, despite adequate anticoagulation treatment. ${ }^{4}$ However, in the United States, a growing liberalization of indications for both permanent and retrievable filters, with a 3 -fold increase in use between 2001 and $2006^{3}$ was observed. Additionally, the overall use of IVCF increased from $9 \%$ in 1993 to $11.4 \%$ in 2012, specifically in massive PE compared with non-massive $(21.3 \%$ vs. $12.4 \%, p<.001) .{ }^{5}$ Although epidemiological data suggested that IVCF could be associated with an improved outcome, opposite data has been shown in a European registry. 3,5 Considering, that in the setting of PE, IVCFs are frequently used in private and non-private medicine, we present our position based on the complex mechanisms of thrombosis, including the inorganic polyphosphate (IPolyP) pathway, the results from randomized controlled trials in terms of outcomes, the absolute risk reduction (ARR) and relative risk reduction (RRR), number needed to treat (NNT), and the FDA recommendations for retrievable IVCF. Furthermore, we analyze the outcome of 290 PE patients submitted to thrombolysis with short-term and long-term follow-up where IVCF had been used in $5 \% .{ }^{6-12}$ 


\section{Rationale for non-routine use of inferior vena cava filters}

\section{Thrombogenic environment}

Patients with PE are an excellent model of thrombosis in a low-pressure compartment within a highly thrombogenic molecular environment. This process is driven by the coagulation system characterized by a cell surface-based model including 3 overlapping phases: initiation, amplification and propagation. ${ }^{13}$ The development of venous thrombosis is the result of a complex interplay involving inflammation, cellular interactions, platelets, and innate immune cells. ${ }^{13}$ The classic pathway includes tissue factor/factor VIla, activated factors, active thrombin, soluble fibrinogen, and a fibrin meshwork. It is important to note that the failure of endogenous fibrinolysis (tissue-type plasminogen activator, platelet activator inhibitor-1, plasmin-antiplasmin complex, D-dimer, thrombin activated fibrinolysis inhibitor, and lipoprotein-a) and depletion of natural antithrombotic proteins (C, S, Z) is key. ${ }^{13}$ In addition to these thrombogenic mechanisms present in all VTE patients, IVCF induces thrombosis by endothelium injury in two specific ways: firstly, at the moment of insertion, by struts adhering tightly to the vascular wall, and secondly, vascular damage secondary to the force required to remove retrievable filters. In all these situations, the endothelial injury induces tissue factor expression and activation of the coagulation classic pathway. ${ }^{13}$

\section{Thrombogenesis of blood-contacting medical devices}

Blood-contacting medical devices (central venous catheters, ports, vascular grafts, stents, heart valves, and IVCF) are widely used in several clinical conditions. Thrombosis is a common and expensive complication of implanted medical devices that can lead to device failure and thromboembolic complications, including $\mathrm{PE}$, stroke, and peripheral embolism. ${ }^{14}$ The intrinsic coagulation pathway, also known as the contact activation pathway, represents the main mechanism involved. In contrast to the healthy endothelium, which actively resists thrombosis, artificial surfaces promote clotting through a complex series of interconnected processes. ${ }^{14}$

IVCF thrombosis is the result of a rapid protein adsorption and platelet adhesion, activation, and aggregation, as well as, simultaneous surface-induced activation via the contact activation pathway. Then, fibrinogen and albumin are the first proteins to get adsorbed along with other adhesive proteins (fibronectin and von Willebrand factor) which mediate platelet adhesion. ${ }^{14}$ The interaction between the bloodstream proteins and an artificial surface, generates a conformational change related to the difference of charges between them, inducing adsorption and forming a monolayer, a mechanism known as Vroman effect. ${ }^{15}$ Fibrinogen is then displaced from the monolayer by other proteins with higher affinities, such as those from the contact system, including factor XII, high molecular weight kininogen, prekalikrein, and factor XI. The activation of factor XII ends up in thrombin generation via the intrinsic pathway and complement activation. ${ }^{14}$

\section{Inorganic polyphosphate in the contact activation pathway}

This molecule has an important role in the setting of IVCF and other medical devices commonly complicated with thrombosis. IPolyP acts at the beginning, the middle, and the end of the blood clotting cascade with prohemostatic, prothrombotic, and proinflammatory effects. ${ }^{16}$ Long-chain polyphosphate is a potent, natural pathophysiologic activator of the contact pathway of blood clotting. IPolyP accelerates factor $\mathrm{V}$ activation, enhances fibrin clot structure, thickens fibrils which are more resistant to fibrinolysis, and promotes factor $\mathrm{XI}$ back-activation by thrombin. This is a common mechanism of thrombosis in medical devices. ${ }^{16}$ Tissue factor pathway inhibitor is thought to be a major endogenous clotting inhibitor, but IPolyP has been shown to abolish its effect on clotting. In fact, IPolyP is a procoagulant that reverses the effect of several anticoagulant drugs (heparin, enoxaparin, rivaroxaban, argatroban), and shortens the clotting times of hemophilic plasma, including in patients being treated with warfarin. ${ }^{16}$ IPolyP also targets the conversion of factor $V$ to factor $\mathrm{Va}$, which is a rate limiting step in blood clotting. Additionally, it could suppress the complement cascade and thus has some antiinflammatory effects. ${ }^{16}$

\section{Inferior vena cava thrombosis}

This is an under-acknowledged complication associated with significant short-term and long-term morbidity and mortality. ${ }^{17}$ In the absence of a congenital anomaly, the most common cause is the presence of an unretrieved IVCF. Due to the substantial increase in the number of IVCF placed in the United States and the very low filter retrieval rates, clinicians are faced with a very large population of patients at risk. Inferior vena cava thrombosis incidence is estimated between $2.6 \%$ and $4.0 \%$ in patients with lower extremity DVT. ${ }^{17}$ However, the true incidence may be underestimated due to the lack of standardized methods of its detection and reporting. The mortality rate is twice as high as that of DVT confined to the lower extremities. If untreated, patients will also suffer from significant morbidities: post-thrombotic syndrome in up to $90 \%$, disabling venous claudication in $45 \%$, $\mathrm{PE}$ in $30 \%$, and venous ulceration in $15 \% .{ }^{17}$

The clinical presentation, diagnosis, and therapeutic approach is challenging for several reasons. The clinical manifestations are often ambiguous and vary significantly according to physician acuity as well as the level and the extent of thrombosis. ${ }^{17}$ Nonspecific back, abdominal, or pelvic pain along with scrotal swelling frequently precede leg symptoms. Considering its insidious onset, the diagnosis is often made after embolism and or venous hypertension symptoms. ${ }^{17}$ Clot migration and embolization into the lungs or renal veins can manifest with dyspnea or oliguria respectively. In addition, there is a paucity of data and guidelines with regards to the diagnosis and management of inferior vena cava thrombosis. ${ }^{17}$ 


\section{Clinical evidence from randomized trials}

\section{Inferior vena cava filter thrombosis and thromboembolism risk in persistently anticoagulated patients}

In a prospective observational cohort, 121 patients had annual physical examinations and ultrasound surveillance of the lower extremity deep veins and in the IVCF site. ${ }^{18}$ Thrombus detected at the IVCF was treated with graded intensities of anticoagulation, depending on the thrombus burden. Symptomatic DVT and PE occurred in 24 patients (20\%; 95\% Cl, 14-28\%) and 6 patients (5\%; 95\% Cl, 2-10\%) respectively. There were 45 episodes of filter thrombus in 36 patients $(30 \%$; $95 \% \mathrm{Cl}, 22-38 \%) .{ }^{18}$ The rate of major bleeding was $6.6 \%$ and similar to that of a concurrent persistently anticoagulated cohort without IVCF filters (5.8\%). ${ }^{18}$ INRs between 2.0 and 3.0 were obtained in symptomatic DVT (62\%), symptomatic PE (65\%), and IVCF thrombosis (77\%). In this group, authors could not establish whether thrombus were formed in situ or resulted from new embolic event. ${ }^{18}$

Finally, the mean follow-up duration for the IVCF group was 3.1 and 3.9 years for the comparison cohort $(p<0.001)$. Shorter follow-up for IVCF patients was due to a higher mortality; 40 IVCF patients died (33\%: 95\% CI, 25\%-42\%), mainly from severe circulatory or respiratory failure or terminal cancer or its complications. ${ }^{18}$ In one patient, death was caused by autopsy-confirmed PE. ${ }^{18}$ The authors also established reasons to offer indefinite anticoagulation if contraindications to anticoagulation remit: (a) thrombus formation within the filter and propagation, reducing filter patency and lower extremity venous return, promoting stasis, and increasing the risk of DVT caudal to the filter; (b) impaired flow due to IVCF may lead to substantial collateral venous return that bypasses the VCF and results in PE recurrence. ${ }^{18}$ These results suggest the necessity of performing an ultrasound as part of the follow-up, and that oral anticoagulation is underuse in IVCF patients. In addition, in those with adequate anticoagulation, the high incidence of recurrence and IVCF thrombosis, with or without clinical expression, ${ }^{18}$ could be attributed to IPolyP's role as a procoagulant reversing the effect of warfarin. ${ }^{16}$

\section{Prevention du Risque d'Embolie Pulmonaire par Interruption Cave study group (PREPIC) studies}

The PREPIC trials ${ }^{19-21}$ included 799 patients who received permanent or retrievable IVCF plus anticoagulation compared with anticoagulation alone. Tables 1 and 2 show the studies' design including number of patients, inclusion and exclusion criteria, interventions, IVCF type, INR measurements and outcomes and follow-up respectively. In brief, PREPIC I ${ }^{19}$ included 400 patients with proximal DVT at risk for PE; 200 patients were under IVCF and 200 patients were nonIVCF. All of them were under effective parenteral and oral anticoagulation. ${ }^{19}$ In a short-term follow-up (day 12) in the IVCF group (1.1\%) compared with the non-IVCF group (5\%) major incidence of symptomatic or asymptomatic PE (OR 0.22 ; 95\% Cl, 0.05-0.90, $p=0.03$ ) was observed ${ }^{19}$ (Table 2). By multivariate analysis, an initial PE with or without clinical expression, was not a significant prognostic indicator of subsequent PE. Recurrent DVT occurred in the IVCF group in $21 \%$ compared with the non-IVCF group in $12 \%$ (OR 1.87 ; $95 \% \mathrm{Cl}, 1.10-3.20 ; p<0.02) .{ }^{19}$ Recurrent VTE in the IVCF group was $21 \%$ compared with the non-IVCF group $16 \%$. In the follow-up, there were no significant differences in mortality $(p 0.16)$ or other outcomes (Table 2$).{ }^{19}$ Considering these results, the conclusion was that in high-risk patients with proximal DVT, the initial beneficial effect of IVCF for the prevention of $P E$ embolism was counterbalanced by an excess of recurrent DVT, without any difference in mortality. ${ }^{19}$

\section{PREPIC extension}

This extension had an 8-year-follow-up and was performed to assess IVCF long-term effect ${ }^{20}$ (Tables 1 and 2). Four hundred patients with proximal DVT with or without PE were randomized either to receive or not an IVCF in addition to standard anticoagulant treatment for at least 3 months (Table 1). Data on vital status, VTE, and post-thrombotic syndrome were obtained annually for up to 8 years. ${ }^{20}$ Outcome data was available in 396 patients (99\%). Vitamin $\mathrm{K}$ antagonists were prescribed for only 3 months after VTE event in $38 \%$ in IVCF group compared with $36 \%$ in non-IVCF group ${ }^{20}$; $35 \%$ in both groups were under vitamin $\mathrm{K}$ antagonists over the entire 8-year study period or until their death. At 8 years, vitamin $\mathrm{K}$ antagonists were being prescribed to $50 \%$ of living patients in both groups. ${ }^{20}$

Symptomatic PE occurred in 6\% (cumulative rate) in the IVCF group compared with $15 \%$ in the nonIVCF group $(p=0.008) .{ }^{20}$ No differences in terms of bleeding complications and mortality in both groups (Table 2). After an adjustment in multivariate analysis, IVCF remained significantly $(p=0.014)$ associated with reduction of embolism. ${ }^{20}$ PE at inclusion was significantly $(p=0.032)$ associated with an increased risk of PE at 8 years. DVT occurred in 57 patients (35.7\%) in the IVCF group and 41 (28\%) in the non-IVCF group (HR 1.52, 95\% Cl 1.02-2.27, $p=0.042) .{ }^{20}$ Of these 98 events, 76 were diagnosed by ultrasonography, 20 by venography, and 2 by contrast-enhanced CT scan. ${ }^{20}$ Cancer diagnosis was associated with a significantly $(p=0.007)$ increased incidence of DVT recurrence at 8 years. Overall, VTE occurred in 58 patients (36\%) in the IVCF group and $55(35 \%)$ in the non-IVCF group $(p=0.54)$. Among these patients, $35(60 \%)$ and $29(54 \%)$, respectively, did not receive a vitamin $\mathrm{K}$ antagonist at the time of VTE recurrence. ${ }^{20}$

Post-thrombotic syndrome was observed in 109 (70\%) and 107 (70\%) patients in the IVCF and non-IVCF groups, respectively. ${ }^{20}$ Approximately half of these patients experienced the first sign of post-thrombotic syndrome within 3 years after the index event. At 8 years, 201 (50\%) patients died, 103 in IVCF group, and 98 in non-IVCF group. ${ }^{20}$ The main causes of death were cancer (49 patients), unexplained death presumed to be of cardiovascular origin (32 patients), cardiac disease (22 patients), and bleeding (17 patients). ${ }^{20}$ PE was directly involved in the death of 7 patients $(1.8 \%)$. Known cancer (HR 2.08, 95\% Cl 1.47-2.95, $p<0.001)$, cardiac or respiratory insufficiency (HR 1.79, 95\% Cl 1.32-2.45, $p<0.001$ ), and age (HR 1.60 per 10 years, $95 \% \mathrm{Cl} 1.37-1.88$, $p<0.001$ ) were the only significant predictors of death at 8 
Table 1 PREPIC series methodology.

\begin{tabular}{|c|c|c|}
\hline Variable & $\begin{array}{l}\text { PREPIC EXTENSION } \\
2005\end{array}$ & PREPIC2 2015 \\
\hline Design & 2 by 2 factorial randomized open trial & $\begin{array}{l}\text { Randomized, open-label, blinded end point } \\
\text { trial }\end{array}$ \\
\hline Patients & 400 patients in 44 French hospitals & $\begin{array}{l}399 \text { patients were randomized in } 17 \text { French } \\
\text { centers }\end{array}$ \\
\hline Inclusion criteria & $\begin{array}{l}\geq 18 \text { years of age } \\
\text { If they have DVT confirmed by venography } \\
\text { with or without concomitant PE } \\
\text { If they were in high risk of PE }\end{array}$ & $\begin{array}{l}\geq 18 \text { years of age } \\
\text { Hospitalized for acute, symptomatic } \\
\text { pulmonary embolism associated with acute } \\
\text { lower-limb deep vein or superficial vein } \\
\text { thrombosis, confirmed by means of standard } \\
\text { objective } \\
\text { Patients had to present at least } 1 \text { additional } \\
\text { criterion for severity: } 75 \text { years, active cancer, } \\
\text { chronic cardiac or respiratory insufficiency, } \\
\text { ischemic stroke with leg paralysis within the } \\
\text { last } 6 \text { months, deep vein thrombosis that } \\
\text { involved the iliocaval segment or was } \\
\text { bilateral, at least } 1 \text { sign of right ventricular } \\
\text { dysfunction or myocardial injury }\end{array}$ \\
\hline Exclusion criteria & $\begin{array}{l}\text { Placement of a previous filter } \\
\text { Contraindication to or failure of } \\
\text { anticoagulant therapy } \\
\text { Curative anticoagulant therapy lasting } \\
\geq 48 \mathrm{~h} \\
\text { Indication of thrombolysis } \\
\text { Short life expectancy } \\
\text { Allergy to iodine } \\
\text { Hereditary thrombophilia } \\
\text { Severe renal or hepatic failure } \\
\text { Pregnancy } \\
\text { Likelihood of noncompliance }\end{array}$ & $\begin{array}{l}\text { Insertion of a vena cava filter was indicated } \\
\text { because of a transient or permanent } \\
\text { contraindication to anticoagulation therapy or } \\
\text { because recurrent thromboembolism had } \\
\text { occurred despite adequate anticoagulant } \\
\text { therapy } \\
\text { Vena cava filter had already been inserted } \\
\text { Thrombosis in the vena cava did not allow } \\
\text { filter insertion } \\
\text { Full-dose anticoagulant treatment had been } \\
\text { administered during } \geq 72 \text { h before } \\
\text { randomization } \\
\text { Patients were also excluded if they had } \\
\text { undergone non-cancer surgery within the past } \\
3 \text { months or cancer surgery within the past } 10 \\
\text { days } \\
\text { Other exclusion criteria were known allergy to } \\
\text { iodinated contrast media, serum creatinine } \\
\text { greater than } 2.04 \text { mg/dL per liter, life } \\
\text { expectancy less than } 6 \text { months, and pregnancy }\end{array}$ \\
\hline Intervention & $\begin{array}{l}\text { IVC filter }(n=200) \text { or no filter }(n=200) \\
\text { LMWH }(n=195) \text { or i.v. UFH }(n=205) \text { for } 8-12 \\
\text { days } \\
\text { From day } 4 \text { and for } \geq 3 \text { months, graded } \\
\text { compression stockings and warfarin or } \\
\text { acenocumarol or, if necessary, UFH }\end{array}$ & $\begin{array}{l}\text { Patients included were assigned to retrievable } \\
\text { IVC filter implantation plus anticoagulation } \\
\text { (filter group; } n=200 \text { ) or anticoagulation alone } \\
\text { with no filter implantation (control group; } \\
n=199 \text { ) }\end{array}$ \\
\hline Types of IVC filters & $\begin{array}{l}\text { Vena Tech LGM (B. Braun), titanium } \\
\text { Greenfield (Boston Scientific), Cardial } \\
\text { (Bard), and Bird's Nest (Cook Group) }\end{array}$ & ALN filter, ALN Implants Chirurgicaux \\
\hline INR & $\begin{array}{l}\text { Vitamin } \mathrm{K} \text { antagonists for } \geq 3 \text { months with } \\
\text { INR of } 2-3 \\
\text { Measured only in the beginning of } \\
\text { anticoagulant therapy }\end{array}$ & $\begin{array}{l}\text { Median percentage of time spent with INR in } \\
\text { an adequate range }(2-3), \% \text { : } \\
\text { Filter group: } 58 \\
\text { No filter group: } 62\end{array}$ \\
\hline
\end{tabular}

The table shows design, number of patients, inclusion and exclusion criteria, intervention, inferior venous cava filters type and INRs in the PREPIC, PREPIC extension and PREPIC2 studies. DVT: deep vein thrombosis; IVC: inferior venous cava; LMWH: low-molecular-weight heparin; PE: pulmonary embolism, UFH: unfractionated heparin. 
Table 2 Outcomes and follow-up in PREPIC series.

\begin{tabular}{|c|c|c|c|c|c|c|}
\hline \multirow[t]{2}{*}{ Variables } & \multicolumn{2}{|c|}{ PREPIC 1998} & \multicolumn{2}{|c|}{ PREPIC EXTENSION 2005} & \multicolumn{2}{|c|}{ PREPIC2 2015} \\
\hline & Filter (\%) & $\begin{array}{l}\text { No filter } \\
(\%)\end{array}$ & Filter (\%) & No filter (\%) & Filter (\%) & No filter (\%) \\
\hline \multirow[t]{2}{*}{$\begin{array}{l}\text { Pulmonary } \\
\text { embolism }\end{array}$} & $\begin{array}{l}\text { At day 12: } \\
2(1 \%)\end{array}$ & $\begin{array}{l}\text { At day } 12: \\
9(4.5 \%)\end{array}$ & Symptomatic & Symptomatic & $\begin{array}{l}\text { At } 3 \text { months: } 6 \\
\text { patients (3\%). } \\
\text { All episodes } \\
\text { were fatal }\end{array}$ & $\begin{array}{l}\text { At } 3 \text { months: } 3 \\
(1.5 \%) \text {. Two } \\
\text { episodes were } \\
\text { fatal }\end{array}$ \\
\hline & $\begin{array}{l}\text { At } 2 \text { years: } \\
6(3 \%)\end{array}$ & $\begin{array}{l}\text { At } 2 \text { years: } \\
12(6 \%)\end{array}$ & $\begin{array}{l}\text { At } 8 \text { years: } 9 \\
(4.5 \%) \text {. Two } \\
\text { episodes were } \\
\text { fatal. }\end{array}$ & $\begin{array}{l}\text { At } 8 \text { years: } \\
24(12 \%) . \\
\text { Five } \\
\text { episodes } \\
\text { were fatal }\end{array}$ & $\begin{array}{l}\text { At } 6 \text { months: } \\
\text { one more } \\
\text { recurrence was } \\
\text { observed }(0.5 \%)\end{array}$ & $\begin{array}{l}\text { At } 6 \text { months: } \\
\text { one more } \\
\text { recurrence was } \\
\text { observed }(0.5 \%)\end{array}$ \\
\hline \multirow[t]{2}{*}{$\begin{array}{l}\text { Deep venous } \\
\text { thrombosis }\end{array}$} & Recurrent & Recurrent & $\begin{array}{l}\text { Symptomatic } \\
\text { recurrent }\end{array}$ & $\begin{array}{l}\text { Symptomatic } \\
\text { recurrent }\end{array}$ & Recurrent & Recurrent \\
\hline & $\begin{array}{l}\text { At } 2 \text { years: } \\
37 \text { (18.5\%) }\end{array}$ & $\begin{array}{l}\text { At } 2 \text { years: } \\
21(10.5 \%)\end{array}$ & $\begin{array}{l}\text { At } 8 \text { years: } 57 \\
(28.5 \%)\end{array}$ & $\begin{array}{l}\text { At } 8 \text { years: } \\
41 \text { (20.5\%) }\end{array}$ & $\begin{array}{l}\text { At } 3 \text { months: } 1 \\
(0.5 \%) \\
\text { At } 6 \text { months: } \\
\text { no recurrence } \\
\text { was observed }\end{array}$ & $\begin{array}{l}\text { At } 3 \text { months: } 1 \\
(0.5 \%) \\
\text { At } 6 \text { months: } \\
\text { one more } \\
\text { recurrence was } \\
\text { observed }(0.5 \%)\end{array}$ \\
\hline $\begin{array}{l}\text { Major } \\
\text { Bleeding }\end{array}$ & $\begin{array}{l}\text { At day } 12: \\
9(4.5 \%) \\
\text { At } 2 \text { years: } \\
17(8.5 \%)\end{array}$ & $\begin{array}{l}\text { At day } 12: \\
6(3 \%) \\
\text { At } 2 \text { years: } \\
22(11 \%)\end{array}$ & $\begin{array}{l}\text { At } 8 \text { years: } 26 \\
(13 \%)\end{array}$ & $\begin{array}{l}\text { At } 8 \text { years: } \\
31(15.5 \%)\end{array}$ & $\begin{array}{l}\text { At } 3 \text { months: } 8 \\
(4 \%) \\
\text { At } 6 \text { months: } \\
\text { five more } \\
\text { recurrences } \\
\text { were observed } \\
(2.5 \%)\end{array}$ & $\begin{array}{l}\text { At } 3 \text { months: } 10 \\
(5 \%) \\
\text { At } 6 \text { months: } \\
\text { five more } \\
\text { recurrences } \\
\text { were observed } \\
(2.5 \%)\end{array}$ \\
\hline Mortality & $\begin{array}{l}\text { At day } 12: \\
5(2.5 \%) \\
\text { At } 2 \text { years: } \\
43(21.5 \%)\end{array}$ & $\begin{array}{l}\text { At day } 12: \\
5(2.5 \%) \\
\text { At } 2 \text { years: } \\
40(20 \%)\end{array}$ & $\begin{array}{l}\text { At } 8 \text { years: } \\
98(49 \%)\end{array}$ & $\begin{array}{l}\text { At } 8 \text { years: } \\
103(51 \%)\end{array}$ & $\begin{array}{l}\text { At } 3 \text { months: } 15 \\
(7.5 \%) \\
\text { At } 6 \text { months: } 6 \\
\text { more } \\
\text { recurrences } \\
\text { were observed } \\
(3 \%)\end{array}$ & $\begin{array}{l}\text { At } 3 \text { months: } 12 \\
(6 \%) \\
\text { At } 6 \text { months: } 3 \\
\text { more } \\
\text { recurrences } \\
\text { were observed } \\
(1.5 \%)\end{array}$ \\
\hline
\end{tabular}

The table shows outcomes including pulmonary embolism, deep venous thrombosis, major bleeding and mortality. Also, follow-up in filter and non-filter patients in the PREPIC, PREPIC extension and PREPIC2 studies.

years. ${ }^{20}$ Based on this evidence, PREPIC extension showed that in an 8-year follow-up, permanent insertion of IVCF reduced the risk of $P E$, increasing DVT without an effect on survival. Although their use may be beneficial in patients with high-risk PE, systematic use in general population with VTE was not recommended. ${ }^{20}$

\section{PREPIC2}

The last French multicentric study ${ }^{21}$ was designed to evaluate the efficacy and safety of retrievable IVCF plus anticoagulation compared with anticoagulation alone for preventing $P E$ recurrence in patients presenting with acute $\mathrm{PE}$ and a high-risk of recurrence. Table 1 shows the studies' design including number of patients, inclusion and exclusion criteria, interventions, IVCF type, INR measurements. Table 2 shown the outcomes in terms of VTE recurrence, bleeding complications and mortality. Filter retrieval was planned at 3 months after placement. ${ }^{21}$ The primary effi- cacy outcome was symptomatic recurrent PE at 3 months. Secondary outcomes were recurrent PE at 6 months, symptomatic DVT, major bleeding, and death at 3 and 6 months, as well as filter complications. ${ }^{21}$

IVCF was successfully inserted in 193 patients and was retrieved as planned in 153 of the 164 patients in whom retrieval was attempted. ${ }^{21}$ Among patients receiving an IVCF, access site hematoma occurred in 5 patients $(2.6 \%)$, IVCF thrombosis in 3 patients (2\%), and retrieval failure due to mechanical reasons in 11 patients $(6 \%) .{ }^{21}$ One patient experienced a cardiac arrest during IVCF insertion. At 3 months, recurrent PE had occurred in 6 patients $(3.0 \%$, all fatal) in the IVCF group and in 3 patients (1.5\%; 2 fatal) in the non-IVCF group (RR with filter, $2.00,95 \% \mathrm{Cl}, 0.51-7.89$, $p=0.50) .{ }^{21}$ Results were similar at 6 months. No difference was observed between both groups regarding other outcomes. Filter thrombosis occurred in 3 patients. ${ }^{21}$ The main cause of death in both treatment groups was cancer. The conclusion was, that among hospitalized patients with severe acute PE, the use of a retrievable IVCF plus 
anticoagulation compared with anticoagulation alone did not reduce the risk of symptomatic recurrent $P E$ at 3 months. These findings do not support the use of this type of filter in patients who can be treated with anticoagulation. ${ }^{21}$

\section{Cancer patients and inferior vena cava filters}

In this population VTE is the second cause of mortality, ${ }^{1}$ anticoagulation is the cornerstone of the treatment, and the anticoagulant of choice is a low-molecular-weight heparin (in acute phase, long-term and extended treatment) until cancer remission. ${ }^{22}$ Despite full anticoagulation, $>20 \%$ of distal VTE propagate, extend into proximal veins, and remain detectable after a year. In addition, up to $50 \%$ of cancer patients will have VTE recurrence in the next 5 years. ${ }^{22}$ In this setting, the benefit of adding an IVCF to anticoagulation in treating cancer patients with VTE remains controversial. The first prospective randomized trial was undertaken to evaluate IVCF placement plus fondaparinux compared with fondaparinux alone in cancer patients. ${ }^{22}$ Sixty-four patients with DVT (86\%) and/or PE (55\%) were included. IVCF were inserted within 3 days of randomization under fluoroscopic guidance; 31 patients were assigned to IVCF plus fondaparinux and 33 patients to receive only fondaparinux. ${ }^{22}$ Patient characteristics in the two treatment groups were similar and no statistically significant differences were found. The most frequent cancer diagnoses were lung $(28 \%)$, breast $(16 \%)$, pancreatic $(14 \%)$, and colon cancers $(11 \%),{ }^{22} 77 \%$ of patients had a stage IV extent of disease, and $13 \%$ had pre-existing stable brain metastases. ${ }^{22}$

No recurrent DVT occurred in either groups and 2 patients (3\%) had new PE, one in each group. ${ }^{22}$ Major bleeding was reported in three patients $(5 \%)$ and 2 patients $(7 \%)$ on the IVCF group had complications from the filter. Median survivals were 493 days in the fondaparinux group and 266 days for IVCF plus fondaparinux $(p<0.57) .{ }^{22}$ Complete resolution of VTE occurred in $51 \%$ of patients within 8 weeks of initiating anticoagulation. The conclusion was that no advantage was found for placement of an IVCF in addition to anticoagulation with fondaparinux in terms of safety, DVT or $\mathrm{PE}$ recurrence, or survival in cancer patients. ${ }^{22}$ Favorable complete resolution rates of thrombosis were observed in both groups. ${ }^{22}$ Additionally, safety and efficacy of fondaparinux in cancer patients was also probed, suggesting that this indirect synthetic factor Xa inhibitor could be another therapeutic option. ${ }^{22}$ Recently, in a retrospective cohort study including 184 DVT patients, 2 groups were compared: patients with DVT plus IVCF without anticoagulation versus anticoagulation alone. The results suggested that IVCF without anticoagulation may be an alternative option for prevention of PE in patients with contraindications to anticoagulant therapy. ${ }^{23}$

\section{Relative and absolute risk reduction, and number needed to treat}

Tables 3 and 4 show RRR, ARR and the NNT of PREPICs ${ }^{19-21}$ and cancer patients ${ }^{22}$ respectively. We estimated RRR, ARR and NNT based on the results of each study using frequency tables. ${ }^{24}$ In the PREPIC study, ${ }^{19}$ placement of IVCF prevented recurrence of $P E$ in the short term, but the tradeoff is the increase in the recurrence of DVT in the long term (RRR: $0.22 ; 95 \% \mathrm{Cl}: 0.04-1.01 ; p<0.05$ and RRR: $1.76 ; 95 \% \mathrm{Cl}$ : $1.07-2.90 ; p<0.02$ ), with an ARR of $3.5 \%$ for recurrence of $P E$ at day 12, without improvement of the short-term mortality (12 day) and follow-up ( 2 years) $(p=1$ and $p=0.71)$. Based on these estimates in the short-term it is necessary to treat 29 patients to prevent PE once. In terms of DVT recurrence, for every 12 patients treated with IVCF, one of them will present an event in the next two-years (Table 3). Therefore, in every 29 patients treated to prevent PE recurrence, 2 will experience DVT recurrence in the follow-up. Considering the sample size and confounders, the NNT could be overestimated in terms of the wide $95 \% \mathrm{Cl}$ (15-319), suggesting the necessity of a randomized control trial with a larger sample and well addressed confounders, to identify the real benefit of IVCF.

In the PREPIC extension, ${ }^{20}$ the trend observed in the first study was maintained. ${ }^{19}$ There was a RRR reduction in relation to PE recurrence (RRR: $0.37 ; 95 \% \mathrm{Cl}: 0.17-0.78 ; p<0.01$ ) with ARR of $7.5 \%$; this means that 14 patients need to be treated with IVCF to prevent one PE recurrence. Meanwhile for DVT recurrence, there was no statistically significant difference in terms of RRR $(p=0.06)$ and mortality $(p=0.68)$. The number needed to harm for DVT recurrence is 12 , so for each prevented PE recurrence there is one DVT recurrence (Table 3). Regarding the PREPIC2 ${ }^{21}$ study, placement of retrievable IVCF plus anticoagulation showed no statistically significant difference in terms of RRR for recurrence of PE and DVT ( $p=0.32, p=0.99$, respectively) at 3 and 6 months $(p=0.37$ and $p=0.56$, respectively). ARR for $\mathrm{PE}$ recurrence was $1.49 \%$ at 3 and 6 months, compared against $0 \%$ and $0.5 \%$ at 3 and 6 months respectively for DVT recurrence, without difference in terms of mortality $(p=0.30)$ (Table 3$)$.

Finally, the Barginear et al. ${ }^{22}$ study regarding IVCF insertion in patients with cancer did not show a statistically significant difference in terms of RRR for recurrence of PE or VTE $(p=0.14, p=0.8$, respectively). Related to ARR, there was a $17.69 \%$ and $22.48 \%$ for recurrence of PE and VTE, respectively. However, these proportions may be related to the reduced sample size (64 patients). Regarding recurrence of DVT alone, authors did not define the number of patients who presented DVT events in each group, so we were not able to estimate RRR and ARR (Table 4). Considering all the evidence, for each recurrence of PE prevented in the first 12 days, 2 DVT recurrences were observed without changes in mortality in the first PREPIC study. ${ }^{19}$ The same trend was observed at the 2-year-follow-up. In the PREPIC extension, ${ }^{20}$ NNT was reduced to 14 patients; however, a similar trend of DVT recurrence was maintained. In the last PREPIC2 study using retrievable IVCF with a short-term follow-up, no benefit was observed in 2 and 3-month follow-up for any of the outcomes established. This evidence suggests that despite the reduction in recurrence of $\mathrm{PE}$, the chronicity of thrombosis in the lower extremities remains a major problem compromising the net benefit of IVCF.

\section{Retrievable inferior vena cava filters and the FDA recommendations}

This class of IVCF began to appear on the market in the early 2000s and were specifically designed to have a less 
Table 3 Relative risk reduction, absolute risk reduction and number needed to treated in the PREPIC, PREPIC extension and PREPIC2 studies.

\begin{tabular}{|c|c|c|c|c|c|c|c|}
\hline Study & Outcomes & $\begin{array}{l}\text { Filter }(\%) \\
n=200\end{array}$ & $\begin{array}{l}\text { No filter }(\%) \\
n=200\end{array}$ & $\operatorname{RRR}(95 \% \mathrm{Cl})$ & $p$ value & ARR\% $(95 \% \mathrm{Cl})$ & NNT \\
\hline \multirow[t]{7}{*}{ PREPIC 1998} & Symptomatic PE at day 12 & $2(1)$ & $9(4.5)$ & $0.22(0.04-1.01)$ & 0.05 & $3.5(0.31-6.69)$ & $29(15-319)$ \\
\hline & Death at day 12 & $5(2.5)$ & $5(2.5)$ & $1(0.29-3.34)$ & 1 & & \\
\hline & Symptomatic PE at 2 years & $6(3)$ & $12(6)$ & $0.50(0.19-1.30)$ & 0.15 & $3(-1.05$ to 7.05$)$ & 34 (NNTH 95 to $\infty$ to NNTB 14 ) \\
\hline & Major bleeding at 2 years & $17(8.5)$ & $22(11)$ & $0.77(0.42-1.41)$ & 0.40 & $2.5(-3.31$ to 8.31$)$ & $\begin{array}{l}40 \text { (NNTH } 30 \text { to } \infty \text { to NNTB 12) } \\
\text { NNH }\end{array}$ \\
\hline & Major bleeding at day 12 & $9(4.5)$ & $6(3)$ & $1.5(0.54-4.13)$ & 0.43 & $1.5(-2.22$ to 5.22$)$ & 66 (NNTH 19 to $\infty$ to NNTB 45 ) \\
\hline & Recurrent DVT at 2 years & $37(18.5)$ & $21(10.5)$ & $1.76(1.07-2.90)$ & 0.02 & $8(1.14-14.86)$ & 12 (NNTH 87 to $\infty$ to NNTH 6$)$ \\
\hline & Death at 2 years & $43(21.5)$ & $40(20)$ & $1.07(0.72-1.57)$ & 0.71 & $1.5(-6.45$ to 9.45$)$ & 66 (NNTH 10 to $\infty$ to NNTB 15 ) \\
\hline & & & & & & & NNT \\
\hline \multirow{6}{*}{ Extension 2005} & Symptomatic PE at 8 years & $9(4.5)$ & $24(12)$ & $0.37(0.17-0.78)$ & 0.0095 & $7.5(2.16-12.84)$ & $14(8-46)$ \\
\hline & Major bleeding at 8 years & $26(13)$ & $31(15.5)$ & $0.83(0.51-1.35)$ & 0.47 & $2.5(-4.35$ to 9.35$)$ & 40 (NNTH 23 to $\infty$ to NNTB 10$)$ \\
\hline & Death at 8 years & $98(49)$ & $102(51)$ & $0.95(0.78-1.15)$ & 0.68 & $2(-7.8$ to 11.8$)$ & $\begin{array}{l}50 \text { (NNTH } 12 \text { to } \infty \text { to NNTB 8) } \\
\text { NNH }\end{array}$ \\
\hline & $\begin{array}{l}\text { Recurrent symptomatic DVT } \\
\text { at } 8 \text { years }\end{array}$ & $57(28.5)$ & $41(20.5)$ & $1.39(0.97-1.97)$ & 0.06 & $8(-0.39$ to 16.39$)$ & $12($ NNTH 6 to $\infty$ to NNTB 254) \\
\hline & Symptomatic VTE at 8 years & $58(29)$ & $55(27.5)$ & $1.05(0.77-1.14)$ & 0.73 & $1.5(-7.32$ to 10.32$)$ & 66 (NNTH 9 to $\infty$ to NNTB 14 ) \\
\hline & Outcomes & $\begin{array}{l}\text { Filter (\%) } \\
n=200\end{array}$ & $\begin{array}{l}\text { No filter }(\%) \\
n=199\end{array}$ & $\operatorname{RRR}(95 \% \mathrm{Cl})$ & $p$ value & ARR\% $(95 \% \mathrm{Cl})$ & NNT \\
\hline \multirow[t]{6}{*}{ PREPIC2 2015} & $\begin{array}{l}\text { New or recurrent DVT at } 3 \\
\text { months }\end{array}$ & $1(0.5)$ & $1(0.5)$ & $0.99(0.06-15.79)$ & 0.99 & 0 (-1.38 to 1.39$)$ & $\begin{array}{l}\text { 39,800 (NNTH } 72 \text { to } \infty \text { to NNTE } \\
72 \text { ) }\end{array}$ \\
\hline & $\begin{array}{l}\text { New or recurrent DVT at } 6 \\
\text { months }\end{array}$ & $1(0.5)$ & $2(1)$ & $0.49(0.04-5.44)$ & 0.56 & $0.5(-1.19$ to 2.20$)$ & 198 (NNTH 84 to $\infty$ to NNTB 45 \\
\hline & Major bleeding & $13(6.5)$ & $15(7.5)$ & $0.86(0.42-1.76)$ & 0.68 & $1.04(-3.98$ to 6.05$)$ & $\begin{array}{l}96 \text { (NNTH } 25 \text { to } \infty \text { to NNTB } 16) \\
\text { NNH }\end{array}$ \\
\hline & $\begin{array}{l}\text { Fatal or non-fatal } \\
\text { symptomatic PE at } 3 \text { months }\end{array}$ & $6(3)$ & $3(1.5)$ & $1.99(0.50-7.84)$ & 0.32 & $1.49(-1.42$ to 4.4$)$ & 67 (NNTH 22 to $\infty$ to NNTB 70) \\
\hline & $\begin{array}{l}\text { Fatal or non-fatal } \\
\text { symptomatic PE at } 6 \text { months }\end{array}$ & $7(3.5)$ & $4(2)$ & $1.74(0.51-5.85)$ & 0.37 & $1.49(-1.72$ to 4.70$)$ & 67 (NNTH 21 to $\infty$ to NNTB 58) \\
\hline & Death & $21(10.5)$ & $15(7.5)$ & $1.39(0.73-2.62)$ & 0.30 & $2.96(-2.65$ to 8.58$)$ & 33 (NNTH 11 to $\infty$ to NNTB 37) \\
\hline
\end{tabular}

RRR: relative risk reduction; ARR: absolute risk reduction; DVT: deep venous thrombosis; NNH: number needed to harm; NNT: number needed to treat; NNTB: number needed to benefit; NNTH: number needed to harm; PE: pulmonary embolism. 
Table 4 Relative risk reduction, absolute risk reduction and number needed to treat in cancer patients.

\begin{tabular}{llllllll}
\hline Study & Outcomes & $\begin{array}{l}\text { Filter }(\%) \\
n=31\end{array}$ & $\begin{array}{l}\text { No filter }(\%) \\
n=33\end{array}$ & RRR (95\%Cl) & $p$ value & ARR\% (95\%Cl) & NNT \\
\hline $\begin{array}{l}\text { Cancer } \\
\text { patients 2012 }\end{array}$ & $\begin{array}{l}\text { Recurrence } \\
\text { PE }\end{array}$ & $18(58)$ & $25(75)$ & $0.76(0.53-1.09)$ & 0.14 & $17.69(-5.01$ to 40.4) & $\begin{array}{l}6 \text { (NNTH 20 to } \infty \\
\text { to NNTB 2) }\end{array}$ \\
& $\begin{array}{l}\text { Recurrence } \\
\text { DVT }\end{array}$ & 48 & 59 & & & & \\
& $\begin{array}{l}\text { Recurrence } \\
\text { DVT and PE }\end{array}$ & $9(29)$ & $17(51)$ & $0.56(0.29-1.07)$ & 0.08 & $22.48(-0.89$ to 45.85) & 5 (NNTH 104 to \\
& & & & & $\infty$ to NNTB 2) \\
\hline
\end{tabular}

ARR: absolute risk reduction; DVT: deep venous thrombosis; NNT: needed number to treat; NNTB: needed number to benefit; NNTH: needed number to harm; PE: pulmonary embolism; RRR: relative risk reduction.

secure implantation to facilitate retrieval. However, despite their widespread use, the indications for the selective use of retrievable IVCF remain uncertain with few trials supporting their use. ${ }^{25}$ In 1999, the US Food and Drug Administration (FDA) downgraded the risk of IVCF from class III to class II; thereby, permitting manufacturers to achieve market approval more readily under the assumption, that new filters were substantially equivalent to other legally marketed devices. ${ }^{26}$ Therefore, several retrievable IVCF were submitted to the FDA and approved as permanent filters with an option for retrieval. ${ }^{25}$ Furthermore, the risks of long-term retrievable IVCF insertion are being increasingly discussed throughout the scientific community, mainstream media, and through multiple class action lawsuits. ${ }^{25}$

Although retrievable IVCF were specifically designed to facilitate retrieval, this advantage has been its most serious downside. In 2010, the FDA disclosed that retrievable IVCF had been associated with more than 900 adverse events. ${ }^{27}$ In addition, multiple reports have demonstrated significant filter-related complications, most commonly linked to duration of implantation, including inferior vena cava penetration or thrombosis, recurrent VTE, filter embolization, as well as displacement and heart migration. . $5,27-29^{\text {There- }}$ fore, in 2014, the FDA released updated recommendations in which physicians were advised to remove filters within 25-54 days of their implantation. However, little evidence exists to show that this recommendation is routinely followed. ${ }^{25}$

Considering the evidence and acknowledging the difficulties of conducting randomized controlled trials in this vulnerable patient population, it is recommended that robust observational studies be undertaken, controlling the confounding indication and severity of the disease. ${ }^{25}$ Currently, Predicting the Safety and Effectiveness of Inferior Vena Cava Filters (PRESERVE) Trial (NCT02381509) is ongoing. This multicentric nonrandomized open label study was designed to determine the safety and effectiveness of commercially available IVCF (retrievable and permanent) in those requiring $P E$ prevention. ${ }^{25}$ Until new evidence emerges, retrievable IVCF should be implanted based on best available evidence and routinely removed within 25-54 days as the FDA has recommended. ${ }^{25}$

\section{Outcome of 290 intermediate, intermediate-high, and -high risk PE patients}

At the beginning of the decade of the nineteen nineties, independent of the risk, the cornerstone of PE treatment was parenteral and oral anticoagulation, and in those with clinical instability, IVCF was the rule. In 1993, our group reported the first successful massive PE case submitted to high-dose $(1,500,000 \mathrm{IU})$ and short-term $(1 \mathrm{~h})$ streptokinase infusion by a peripheral vein. ${ }^{6}$ This was the first report in world literature in which streptokinase at high dose and rapid infusion was effective and safe in a massive PE patient. Previously, this streptokinase regimen had been used in hundreds of thousands of ST-elevation myocardial infarction patients with excellent results. This case also supported the echocardiogram role in emergency room department (ERD) and the possible relevance of an electrocardiogram as an indirect indicator of reperfusion. ${ }^{6-10}$

Immediately, our group integrated the first thrombolysis (peripheral vein) fast-track program in PE patients in ERD at the Hospital de Cardiologia, Centro Medico Nacional "Siglo XXI, IMSS". This program included a multidisciplinary approach (emergency, echocardiography, and nuclear medicine cardiologists) with a main target: fast reaction starting thrombolysis in the first 90 min after patient arrives. ${ }^{6-10}$ Two years later, a similar program was performed in ERD at Hospital de Cardiología No 34, IMSS in Monterrey, Mexico. In both programs from 1992 to 2010, ${ }^{11,12}$ 290 PE patients with extensive thrombotic burden, severe pulmonary hypertension, and right ventricular dysfunction in which IVCF was used in $5 \%$ only. ${ }^{6,8,9,11,12}$ Table 5 shows PE characteristics, anticoagulation, thrombolytic regimen, IVCF use, as well as in-hospital and follow-up outcomes.

In 5 studies including 212 PE patients, $, 6,8,9,12$ the proportion of PE and DVT recurrence was $3 \%$ to $17 \%$ and $0 \%$ respectively (Table 5 ). The in-hospital bleeding complications rate was $3 \%$ to $19 \%$ where no patient had an IVCF inserted. Considering that DVT tests were not performed in the follow-up, we cannot exclude asymptomatic DVT recurrence. In 2009, our investigative study reported the results of the first prospective, multicenter, openlabel, controlled, two-year follow-up trial in high-risk PE patients. We proved that, a weight-adjusted unfractionated heparin dose followed by enoxaparin as an adjunct to onehour alteplase infusion, improved in-hospital and follow-up outcome without increasing bleeding complications, compared to unfractionated heparin alone. ${ }^{11}$ The control group included, high-risk PE patients whose thrombolysis was not used due to contraindication, risk of major bleeding, patient rejection, and/or the attending physician's decision. Forty patients entered in alteplase plus, unfractionated heparin plus enoxaparin group, and 40 patients were in the 
Table 5 Pulmonary embolism severity, anticoagulation, thrombolysis regimen, IVCF use, outcomes and follow-up.

\begin{tabular}{|c|c|c|c|c|c|c|c|c|c|c|}
\hline Author, year & $\begin{array}{l}\text { No. } \\
\text { patients }\end{array}$ & Diagnosis & Anticoagulation & Thrombolysis & $\begin{array}{l}\text { IVCF } \\
N(\%) \\
\end{array}$ & $\begin{array}{l}\text { PE recurrence } \\
N(\%)\end{array}$ & $\begin{array}{l}\text { DVT recurrence } \\
N(\%)\end{array}$ & $\begin{array}{l}\text { Mortality } \\
N(\%)\end{array}$ & $\begin{array}{l}\text { Bleeding } \\
N(\%)\end{array}$ & Follow-up \\
\hline $\begin{array}{l}\text { Jerjes-Sanchez } \\
\text { et al., } 1993^{6}\end{array}$ & 1 & Massive & UFH + Warfarin & $\begin{array}{l}1,500,000 \mathrm{IU} \\
\text { Streptokinase }\end{array}$ & $0(0 \%)$ & $0(0 \%)$ & $0(0 \%)$ & $0(0 \%)$ & $0(0 \%)$ & 3 months \\
\hline $\begin{array}{l}\text { Jerjes-Sanchez } \\
\text { et al., } 1995^{8}\end{array}$ & 8 & Massive & $\begin{array}{l}4 \text { patients } \\
\text { UFH } \\
10,000 \mathrm{IU}+\text { Warfarin } \\
4 \text { patients } \\
\text { UFH } \\
10,000 \mathrm{IU}+\text { Warfarin }\end{array}$ & $\begin{array}{l}4 \text { patients } \\
1,500,000 \mathrm{IU} \\
\text { Streptokinase } \\
\text { No }\end{array}$ & $0(0 \%)$ & $\begin{array}{l}0(0 \%) \\
\text { NA }\end{array}$ & $\begin{array}{l}0(0 \%) \\
\text { NA }\end{array}$ & $\begin{array}{l}0(0 \%) \\
4(100 \%)\end{array}$ & $\begin{array}{l}0(0 \%) \\
\text { NA }\end{array}$ & 2 years \\
\hline $\begin{array}{l}\text { Jerjes-Sánchez } \\
\text { et al., } 2001^{9}\end{array}$ & 40 & $\begin{array}{l}\text { Large or } \\
\text { massive }\end{array}$ & $\begin{array}{l}10,000 \mathrm{IU} \\
\text { UFH + Warfarin }\end{array}$ & $\begin{array}{l}1,500,000 \\
\text { Streptokinase }\end{array}$ & $0(0 \%)$ & $\begin{array}{l}\text { In hospital: } 7 \\
(17 \%)\end{array}$ & $0(0 \%)$ & $\begin{array}{l}\text { In hospital: } 5 \\
(12 \%) \\
7 \text { years: } 0 \\
(0 \%)\end{array}$ & $\begin{array}{l}\text { In hospital: } 1 \\
(2 \%)\end{array}$ & $\begin{array}{l}7 \text { years ( } 2 \text { patients } \\
\text { were lost) }\end{array}$ \\
\hline $\begin{array}{l}\text { Jerjes-Sánchez } \\
\text { et al, 200911 }\end{array}$ & 80 & High-risk & $\begin{array}{l}40 \text { patients weight } \\
\text { adjusted } \\
\text { UFH + Enoxaparin + } \\
\text { Warfarin }\end{array}$ & $\begin{array}{l}100 \mathrm{mg}, 1 \mathrm{~h} \\
\text { Alteplase }\end{array}$ & $\begin{array}{l}\text { In hospital } \\
1(3 \%)\end{array}$ & $\begin{array}{l}\text { In hospital: } \\
4(10 \%) \\
30 \mathrm{~d}(n=39): \\
0(0 \%) \\
90 \mathrm{~d}(n=39): \\
1(3 \%) \\
180 \mathrm{~d}(n=39): \\
0(0 \%) \\
\text { In hospital } \\
8(20 \%) \\
30 \mathrm{~d}(n=30): \\
1(3 \%) \\
90 \mathrm{~d}(n=29): \\
2(7 \%) \\
180 \mathrm{~d}(n=27): \\
6(22 \%)\end{array}$ & $\begin{array}{l}0(0 \%) \\
0(0 \%) \\
0(0 \%) \\
0(0 \%) \\
0(0 \%) \\
2(7 \%) \\
2(7 \%) \\
7(26 \%)\end{array}$ & $\begin{array}{l}\text { In hospital } \\
1(3 \%) \\
0(0 \%) \\
0(0 \%) \\
0(0 \%) \\
\text { In hospital } \\
10(25 \%) \\
1(3 \%) \\
2(7 \%) \\
2(7 \%)\end{array}$ & $\begin{array}{l}\text { In hospital } \\
5(13 \%) \\
0(0 \%) \\
0(0 \%) \\
0(0 \%) \\
\text { In hospital } \\
5(13 \%) \\
0(0 \%) \\
0(0 \%) \\
0(0 \%)\end{array}$ & 2 years \\
\hline $\begin{array}{l}\text { Jerjes-Sánchez } \\
\text { et al., } 2015^{12}\end{array}$ & 131 & $\begin{array}{l}70 \text { patients } \\
\text { with no RVH }\end{array}$ & $\begin{array}{l}5000 \text { or } 10,000 \mathrm{IU} \\
\text { of UFH + Warfarin }\end{array}$ & $\begin{array}{l}\text { 1, 500, } 000 \mathrm{IU} \\
\text { of Streptokinase }\end{array}$ & $0(0 \%)$ & $\begin{array}{l}\text { In hospital } \\
(n=61): \\
10(16 \%) \\
7 \% \text { of total } \\
\text { patients } \\
\text { In hospital } \\
(n=70): 4(6 \%) \\
3 \% \text { of total } \\
\text { patients }\end{array}$ & $0(0 \%)$ & $\begin{array}{l}\text { In hospital } \\
(n=61): \\
17(28 \%) \\
12 \% \text { of total } \\
\text { patients } \\
\text { In hospital } \\
(n=70): 0 \\
(0 \%) \\
0 \% \text { of total } \\
\text { patients }\end{array}$ & $\begin{array}{l}\text { In hospital } \\
(n=61): \\
12(19 \%) \\
9 \% \text { of total } \\
\text { patients } \\
\text { In hospital } \\
(n=70): \\
6(8 \%) \\
4.5 \% \text { of total } \\
\text { patients }\end{array}$ & $\begin{array}{l}17 \text { years (Jan } \\
1996-\text { Dec } 2013) \\
6 \text { patients with RVH, } \\
\text { and } 7 \text { without were } \\
\text { lost to follow-up } \\
\text { ( } 4.5 \% \text { and } 5 \% \text { of total) }\end{array}$ \\
\hline $\begin{array}{l}\text { Jerjes-Sánchez } \\
\text { et al., } 2015^{12}\end{array}$ & 30 & $\begin{array}{l}\text { Intermediate } \\
\text { high-risk }\end{array}$ & $\begin{array}{l}\text { Weight-adjusted } \\
\text { intravenous } \\
\text { UFH + Enoxaparin + W }\end{array}$ & $\begin{array}{l}\text { Tenecteplase } \\
\text { bolus } 5 \mathrm{seg} / \mathrm{kg} \\
\text { rfarin }\end{array}$ & $0(0 \%)$ & $\begin{array}{l}\text { In hospital: } 1 \\
(3 \%) \\
6 \mathrm{~m}: 0(0 \%)\end{array}$ & $0(0 \%)$ & $\begin{array}{l}\text { In hospital: } \\
4(13 \%) \\
6 \mathrm{m:} 0(0 \%)\end{array}$ & $\begin{array}{l}\text { In hospital: } \\
4(13 \%) \\
6 \mathrm{m:} 0(0 \%)\end{array}$ & 6 months \\
\hline
\end{tabular}

term follow-up. DVT: deep vein thrombosis; IVCF: inferior vena cava filter; PE: pulmonary embolism; RVH: right ventricular hypokinesia; UFH: unfractionated heparin. 
control group. IVCF was used as the only treatment in $43 \%$ of patients because of contraindications to thrombolysis and to parenteral anticoagulation (Table 5). Although the study target was not to compare thrombolysis and anticoagulation versus IVCF, we observed a clear trend against either IVCF or unfractionated heparin in terms of in-hospital and followup outcomes (Table 5). The evidence identified favorable in-hospital and follow-up outcomes in patients submitted to successful thrombolysis and extension treatment over 5 years; utilizing this data, it is not possible to take or imply any decision for using or not using IVCF. $6,8,9,11,12$

\section{Final considerations}

At the beginning, ${ }^{6,8,9,11}$ our position to offer indefinite oral anticoagulation in intermediate, intermediate-high, and high-risk PE patients instead of IVCF was based on: (a) IVCF as a foreign body may initiate and propagate thrombus from inside, reducing patency and venous return, promoting stasis and DVT recurrence; (b) small thrombi passing through patent filters or collateral venous return bypassing IVCF could result in PE recurrence; (c) in spite of IVCF, sooner or later patients will require long-term oral anticoagulation; (d) lack of evidence from randomized controlled trials; (e) expensive and invasive treatment. This position was sustained in 290 PE patients in whom in-hospital and short-term or long-term follow-up VTE recurrence was less than expected.

To support our previous and current position, new evidence has been added, as complex thrombosis pathways, including IPolyP as a procoagulant reversing several anticoagulant drugs, and IVCF as a thrombogenic risk factor. Furthermore, evidence from randomized controlled trials do not support IVCF use in cancer and non-cancer PE patients. ${ }^{22,29}$ Finally, following European Society of Cardiology guidelines, we recommend IVCF use in PE patients with proved DVT and absolute contraindications for anticoagulant drugs or with objectively confirmed recurrent PE despite adequate anticoagulation treatment. ${ }^{4}$ Until new evidence is available, retrievable IVCF should be implanted and routinely removed within 25 to 54 days as the FDA has recommended. ${ }^{24}$ Considering the complex mechanisms of thrombosis related with IVCF, the evidence from randomized control trials and ARR, RRR, and NNT obtained from venous thromboembolism patients with and without cancer, non-routine use of IVCF is recommended.

\section{Funding}

None.

\section{Conflict of interest}

The authors declare no conflict of interest.

\section{Acknowledgement}

Dr. Kristopher J. Currie G for editorial assistance.

\section{References}

1. Jerjes-Sánchez C. Mechanisms of thrombosis. In: JerjesSanchez C, editor. Thrombolysis in pulmonary embolism. Heidelberg/New York/Dordretcht/London/Switzerland: Springer Cham/Springer International Publishing; 2015. p. 1-14.

2. Jiménez D, de Miguel-Diaz J, Guijarro R, et al., for the RIETE Investigators. Trends in the management and outcomes of acute pulmonary embolism. J Am Coll Cardiol. 2016;67:162-70.

3. Konstantinides SV, Barco S, Lankeit M, et al. Management of pulmonary embolism. J Am Coll Cardiol. 2016;67:976-90.

4. Konstantinides SV, Torbicki A, Agnelli G, et al. 2014 ESC guidelines on the diagnosis and management of acute pulmonary embolism. Eur Heart J. 2014;35:3033-69.

5. Smith SB, Geske JB, Kathuria P, et al. Analysis of national trends in admissions for pulmonary embolism. Chest. 2016;150:35-45.

6. Jerjes-Sánchez C, Ramírez RA, Arriaga NR, et al. Dosis altas e infusión rápida de estreptoquinasa para el tratamiento de tromboembolia pulmonar masiva. Arch Inst Cardiol Mex. 1993;63:22734.

7. Jerjes-Sanchez C, Gutierrez-Fajardo P, Ramirez-Rivera A, et al. Infarto agudo del ventrículo derecho secundario a tromboembolia pulmonar masiva. Arch Inst Cardiol Mex. 1995;65:6573.

8. Jerjes-Sanchez C, Ramirez-Rivera A, Garcia ML, et al. Streptokinase and heparin versus heparin alone in massive pulmonary embolism: a randomized controlled trial. J Thromb Thrombolysis. 1995;2:67-9.

9. Jerjes-Sanchez C, Ramirez-Rivera A, Arriaga-Nava R, et al. High dose and short-term streptokinase infusion in patients with pulmonary embolism. Prospective with seven-year follow-up trial. J Thromb Thrombolysis. 2001;12:237-47.

10. Ramirez-Rivera A, Gutierrez-Fajardo P, Jerjes-Sanchez C, et al. Acute right myocardial infarction without significant obstructive coronary lesions secondary to massive pulmonary embolism. Chest. 1993;104:80S.

11. Jerjes-Sanchez C, Villarreal-Umaña S, Ramirez-Rivera A, et al. Improving adjunctive treatment in pulmonary embolism and fibrinolytic therapy. The role of enoxaparin and weightadjusted unfractionated heparin. J Thromb Thrombolysis. 2009;27:154-62.

12. Jerjes-Sánchez C. Thrombolysis in pulmonary embolism. In: Jerjes-Sánchez C, editor. Thrombolysis in pulmonary embolism. Heidelberg/New York/Dordretcht/London/Switzerland: Springer Cham/Springer International Publishing; 2015. p. 175-207.

13. Jerjes-Sánchez C. Mechanisms of thrombosis. In: JerjesSánchez C, editor. Thrombolysis in pulmonary embolism. Heidelberg/New York/Dordretcht/London/Switzerland: Springer Cham/Springer International Publishing; 2015. p. 1-14.

14. Jaffer IH, Fredenburgh JC, Hirsh J, et al. Medical deviceinduced thrombosis: what causes it and how can we prevent it. J Thromb Haemost. 2015;13:S72-81.

15. Hirsh SL, McKenzie DR, Nosworthy NJ, et al. The Vroman effect: competitive protein exchange with dynamic multilayer protein aggregates. Colloids Surf B: Biointerfaces. 2013;103:395-404.

16. Morrissey JH, Choi SH, Smith SA. Polyphosphate: an ancient molecule that links platelets, coagulation and inflammation. Blood. 2012;119:5972-9.

17. Alkhouli M, Morad M, Narins CR, et al. Inferior vena cava thrombosis. J Am Coll Cardiol Cardiovasc Interv. 2016;9:629-43.

18. Hajduk B, Tomkowski WZ, Matek G, et al. Vena cava filter occlusion and venous thromboembolism risk in persistently anticoagulated patients: a prospective, observational cohort study. Chest. 2010;137:877-82.

19. Decousus H, Leizorovicz A, Parent F, et al., for the Prévention du Risqué d'Émbolie Pulmonaire par Interruption Cave Study Group. A clinical trial of vena cava filters in the prevention 
of pulmonary embolism in patients with proximal deep-vein thrombosis. N Engl J Med. 1998;338:409-15.

20. The PREPIC Study Group. Eight-year follow-up of patients with permanent vena cava filters in the prevention of pulmonary embolism. The PREPIC (Prévention du Risque d'Embolie Pulmonarire par Interruption Cave) randomized study. Circulation. 2005;112:416-22.

21. Mismetti P, Laporte S, Pellerin O, et al., for the PREPIC2 Study Group. Effect of retrievable inferior vena cava filter plus anticoagulation vs anticoagulation alone on risk of recurrent pulmonary embolism. A randomized clinical trial. JAMA. 2015;313:1627-35.

22. Barginear MF, Gralla RJ, Bradley TP, et al. Investigating the benefit of adding a vena cava filter to anticoagulation with fondaparinux sodium in patients with cancer and venous thromboembolism in a prospective randomized clinical trial. Support Care Cancer. 2012;20:2865-72.

23. Zektser M, Bartal C, Zeller L, et al. Effectiveness of inferior vena cava filters without anticoagulation therapy for prophylaxis of recurrent pulmonary embolism. Rambam Maimonides Med J. 2016;7:e0019.

24. Altaman DG. Confidence intervals for the number needed to treat. BMJ. 1998;317:1309-12.

25. Arous EJ, Messina LM. Temporary inferior vena cava filters. Chest. 2016;149:1143-5.

26. Guidance for cardiovascular intravascular filter $510(\mathrm{k})$ submissions; 1999. http://www.fda.gov/downloads/MedicalDevices/ DeviceRegulationandGuidance/GuidanceDocuments/ ucm073777.pdf [accessed 21.03.16].

27. Removing retrievable inferior vena cava filters: initial communication; 2010. http://www.fda.gov/MedicalDevices/ Safety/AlertsandNotices/ucm221676.htm [accessed 06.09.16].

28. Kassi M, Lopez J, Barker C, et al. It wasn't cupid: multimodality imaging of inferior vena cava filter fracture with strut migration to the interventricular septum. MDCV. 2014;13:198-200.

29. Morales JP, Li X, Irony TZ, et al. Decision analysis of retrievable inferior vena cava filters in patients without pulmonary embolism. J Vasc Surg Venous Lymphat Dis. 2013;1:376-84. 